\title{
Article
}

\section{Anti-corruption Coordinative Mechanism between the ICSID and Domestic Enforcement Authorities: A China's Perspective*}

\author{
Hongwu Yin ${ }^{* *}$
}

When confronted with the host states' increasing enthusiasm of invoking the corruption defense as an arbitral strategy to frustrate foreign investors' claims, the International Centre for Settlement of Investment Disputes (ICSID) tribunals encounter realistic difficulties in arbitration. The inherent insufficiency of anti-corruption investigative powers bestowed to ICSID tribunals highlights the importance of constructing a coordinative mechanism between the ICSID and any domestic enforcement authorities enlisted to repudiate corruption. The enacted International Criminal Judicial Assistance Law of the People's Republic of China provides the domestic legal basis for establishing a coordinative international criminal judicial assistance mechanism between such international organizations as ICSID and China's domestic anti-corruption enforcement authorities. Eventually, the proposed ICSID-China's anti-corruption mechanism will help the global community fight against international investment corruption in a coordinated way, substantially enhancing any host state's ability to confront the on-going difficulties also experienced by investment arbitral tribunals.

* This article is supported by the Research Program of Justice Department of Hunan Province, PRC: "The Construction and Perfection of the Legal System in Hunan Free Trade Pilot Zone" [湖南自 贸试验区法律制度的构建与完善] (2020-2021); “Bilingual Teaching Practices of International Law Course" [国际法学课程双语教学实践研究] (2018); and “Construction Program of the First-Class Discipline" in Hunan Normal University.

** Associate professor of International Law at Hunan Normal University, PRC. A.B. (Hunan U. Sci. \& Tech.), A.M. (Zhejiang U.), Ph.D. (Hunan Normal U.). ORCID: https://orcid.org/0000-0002-55907510. The author may be contacted at: lawschool2014@163.com/Address: Law School of Hunan Normal University, 36\# Lushan Road, Yuelu District, Changsha Hunan Province, PRC.

All the websites cited in this article were last visited on February 3, 2021. 
Keywords: ICSID Anti-Corruption Arbitral Practice, Realistic Difficulties, Domestic AntiCorruption Enforcement Authorities, International Anti-Corruption Coordinative Mechanism

\section{INTRODUCTION}

The settlement of international investment disputes has aroused wide concern since the beginning of the 21 st century. Undoubtedly, the "corruption" element makes the settlement of international investment disputes more complicated. Currently, investment arbitration tribunals can offer effective anti-corruption mechanisms, as they are outside the domestic sphere. On one hand, tribunals secure foreign investors free from adjudication by a potentially corrupt municipal judicial system. On the other, awards made by the International Centre for Settlement of Investment Disputes (ICSID) tribunals are relevantly transparent and open to the public with strong enforceability. ${ }^{1}$ However, international investment arbitral tribunals play a passive role in managing corruption-involved international investment disputes and the arbitral jurisprudence employed by current tribunals is subject to criticisms for the asymmetrical treatment of the interests of foreign investors and the host state, which tends to negatively influence international investment practices. Therefore, the many challenges confronted by investment tribunals need to be carefully considered.

The primary purpose of this research is to propose a representative coordinative international criminal judicial assistance mechanism between ICSID and China's domestic anti-corruption enforcement authorities on the legal basis of the International Criminal Judicial Assistance Law of the People's Republic of China in an attempt to solve the present difficulties confronted by investment arbitration tribunals in deciding corruption-involved cases. This paper is composed of five parts including Introduction and Conclusion. Part two will examine realistic difficulties in the ICSID anti-corruption arbitrations. Part three will discuss legal basis for constructing an anti-corruption coordinative mechanism. Part four will analyze anti-corruption coordinative strategies of the ICSID tribunals. 


\section{Realistic Difficulties In the ICSID Anti-CORRUPTION Arbitrations}

When confronted with the corruption defense invoked by host states, investment arbitral tribunals need to pose four questions relevant to the features of the defense before considering whether or not to accept the states' assertions. First, what is the nature of the investor's alleged corrupt misconduct? Second, what law (or laws) shall be applied by the investment arbitral tribunals? Third, how evidentiary burden shall be allocated between the parties? And fourth, what are the appropriate remedies for both disputing parties? Unfortunately, the tribunals' responses to these questions are not always satisfactory.

\section{A. Nature of International Investment Corrupt Activities}

Investment tribunals are obliged to make certain whether the investment corrupt misbehaviors concerned are unilateral or bilateral in nature and distinguish meticulously between "hard corruption" and "soft corruption." Hard corruption is the offer or promise of an undue advantage to a public official to gain an improper advantage. It may be done directly or through an intermediary. ${ }^{2}$ It entails "an intentional act pursued with the purpose of influencing a public official in the performance of his or her official duties, which in turn is directed at gaining an undue business advantage." The "soft" form of corruption or "influence peddling" is essentially an attenuated form of hard corruption. It entails the offer or promise of an undue advantage to a person who claims to be able to exert an undue influence on a public official. ${ }^{4}$ Whereas several ICSID tribunals have upheld the corruption defense in cases of hard corruption, ${ }^{5}$ no tribunal has allowed a state to invoke the defense for "mere" influence peddling. ${ }^{6}$

Meanwhile, tribunals must measure the severity of the investors' wrongful conduct. Additionally, tribunals are never encouraged to adjudicate all investment involving investor's illegality as "disqualified investment" outside the realm of international investment law protection, hence decline to exercise the jurisdiction. In summation, when handling the host state's corruption defense, investment tribunals are supposed to make distinctions between different investment corrupt cases by probing into the nature of corrupt misconduct committed by foreign investors instead of showing their own practically fact-finding limitations of 
roughness and rashness.

\section{B. Arbitral Tribunals' Declination of Jurisdiction over Investment Disputes}

In general, ICSID tribunals' affirmation of the host state's corruption defense is mainly based on three legal causes: (a) international (transnational) public policy theory; (b) requirement for investment to be made "in accordance with laws and regulations"; and (c) parties' obligation to act in good faith. ${ }^{7}$ Although the tribunal in Inceysa seems to have incorporated notions of "good faith" and "international public policy" into "the requirement that an investment be made in accordance with laws," other ICSID arbitral case law suggests that the first two principles are indeed separate justifications that tribunals may invoke in the absence of an "in accordance" provision. ${ }^{8}$ Overall, regarding the corruption-involved disputes, if foreign investors invested in a way violating the treaty's "in accordance" provision, the "investing" act does not result in an eligible "investment" under specific bilateral investment treaty (or other treaties), so that the investors are unable to enjoy the protective rights under the investment treaty. ${ }^{9}$ Since the investment does not qualify "the covered investment by the treaty," there exists no automatically-concluded arbitration agreement between the investor and host state. Consequently, ICSID tribunals lack jurisdiction over the investment disputes concerned. ${ }^{10}$ In contrast, when the investment treaty does not contain an "in accordance" express clause, tribunals can still impose qualifying requirements for foreign investment in pursuing BIT substantive protective rights on the basis of "international public policy" and "general law principles." "Hence, the tribunals assert their jurisdiction over the case, but investors' claims cannot be upheld since the latter has failed to acquire the rights by invoking the relevant investment treaties. $^{12}$

Article 42 (1) of the ICSID Convention provides: "The Tribunal shall decide a dispute in accordance with such rules of law as may be agreed by the parties. In the absence of such an agreement, the Tribunal shall apply the law of the Contracting State party to the dispute (including its rules on the conflict of laws) and such rules of international law as may be applicable." In arbitration practice, however, the investment tribunals are inclined to pursue "roughness," avoiding "delicacy," when choosing the applicable laws to decide disputes - specifically, relying excessively on "in accordance" provisions in investment treaties or 
general law principles. ${ }^{13}$ Tribunals tend to adjudicate the disputes in a "rough line" approach while overlooking the "delicate and accurate" application of the host states' domestic legal rules. ${ }^{14}$ Several problematic issues exist in the current international investment arbitration case law that is not solved by investment tribunals as follows.

Firstly, "in accordance with the host state laws" requirement is not one of the necessary and objective factors for evaluating a "qualified" investment. ${ }^{15}$ Secondly, numerous Bilateral Investment Treaties (BITs) revised in recent years also excluded the "in accordance" factor from the "investment" definition provision. The China-Germany BIT is a typical example. Although the "in accordance" factor is explicitly required in defining the "investment" in the 1983 China-Germany BIT, ${ }^{16}$ the revised 2003 version does not contain this requirement. ${ }^{17}$ The 2004 China-Uganda BIT stipulates the same type of provision as in the 2003 China-Germany BIT. ${ }^{18}$ Thirdly, the "in accordance" clause shall be applied specifically in combination with certain stipulations under the domestic law framework, thereby thoroughly overcoming any uncertainty problems ${ }^{19}$ in the practical application of any "in accordance" clause. Finally, an investor could potentially assert an affirmative defense of "estoppels" to block the corruption defense if the host state endorsed the investment while "knowingly overlooking" the investor's conduct is not compliant with its laws. ${ }^{20} \mathrm{Up}$ to now, though no tribunal has yet invoked "estoppels" ${ }^{\text {"21 }}$ or taken into account any of the mitigating factors $^{22}$ when confronted with the corruption defense, tribunals are naturally responsible for a comprehensive consideration of all these factors as well as the "estoppels" principle.

\section{Uniform Evidentiary Standard and the ICSID Tribunals}

As pre-empted, some uncertainties already exist concerning the technical details of the three rationales that have been employed in support of the host state's corruption defense in previous ICSID arbitral proceedings. ICSID jurisprudence is especially obscure about the evidentiary burden that each disputing party should bear. ${ }^{24}$ Until now, few tribunals have specified the evidentiary criterion in deciding the corruption-involved cases, ${ }^{25}$ but others have failed to define a precise standard. It is unclear what standard will emerge as the rule for future ICSID tribunals to observe when settling any corruption-involved investment disputes. Tribunals 
have been reluctant to inquire deeply into allegations of corruption even when further evidence may be available. When domestic investigations into improper international commercial conduct have been ongoing, tribunals have not waited for the outcome of these investigations. ${ }^{26}$

\section{1. "Clear and Convincing Evidence" Standard}

Previously, the tribunal for Siag v. Arab Republic of Egypt applied the American standard of "clear and convincing evidence," which lies somewhere between the traditional civil standard of "preponderance of the evidence" (also referred to as the "balance of probabilities") and the criminal standard of "beyond reasonable doubt." ${ }^{27}$ The tribunal held that the standard was appropriate not only because the claimant had adduced a great deal of prima facie evidence to prove that he had not committed fraud, but also because serious allegations (such as fraud) demand a higher standard of proof. ${ }^{28}$

\section{The Evidentiary Standard Applied by Most Tribunals}

When confronted with the corruption defense invoked by the respondent-host state, most tribunals have held that the evidence adduced by the latter has not been sufficient to support the defense. However, they have also failed to define the precise evidentiary standard that should be applied in settling disputes. ${ }^{29}$ Nonetheless, tribunals do agree that the burden should be high: "An accusation of bribery requires the most rigorous level of proof. ${ }^{, 30}$ Specifically, the evidence to support the corruption accusation needs to highly credible. ${ }^{31}$ Naturally, different voices emerged during arbitral practice. In Siag, one dissenting arbitrator argued for a lower standard of proof, thereby allowing the tribunals' discretion to make inferences based on "concordant circumstantial evidence." 32 However, no tribunal has yet applied this standard as the arbitrator suggested.

\section{Loss of Interest Balance between Disputing Parties}

An additional issue of the corruption defense worthy of serious consideration concerns the remedies available to the investment disputing parties. Although the applied reasoning of tribunals has varied, the ultimate remedy depends on both the source of the ICSID jurisdiction ${ }^{33}$ and the law applied by the tribunal. Inferring from the past practice of international investment arbitration, it would 
be concluded that some ICSID tribunals claim no jurisdiction over corruptioninvolved investment disputes, while in other cases even when tribunals (e.g. in World Duty-Free Co. v. the Republic of Kenya ${ }^{34}$ ) do exercise jurisdiction over the dispute, they usually hold that the investor's corrupt misconduct has rendered the contract voidable at the respondent-host state's option. Even then, the contract was not void ab initio; the respondent-host state was required to act to set it aside. Concerning the remedies offered to foreign investors (or investments) suspicious of corruption involvement, it is strongly proposed to follow the principle of "restitutio in integrum," which entails restoring the parties to their original positions, but does not include returning the bribe to the bribe payer. ${ }^{35}$

Unfortunately, the jurisprudential doctrine of "unclean hands" used by previous investment tribunals closed the doors to those investors (investments) tainted with "inequitableness or bad faith" stains relevant to the corruption misconducts, no matter how improper the behavior of the host state as the defendant may have been. ${ }^{36}$

It is obvious that the remedies offered to both disputing parties by tribunals causes a substantial asymmetry of interest protections between foreign investors and the host states. To begin with, foreign investors are not expected to become the only entity to bear all the unfavorable consequences in the investment arbitration proceedings. ${ }^{37}$ Additionally, tribunals' declination to exercise jurisdiction over the dispute makes the potential legal liabilities on the part of the host state (or its officials) exempt from any punishment or even criminal charges. Finally, tribunals' adjudicatory reasoning takes no account of the old civil law principle of "unjust enrichment," which means the host state is obliged to return the lawful investment instead of possibly having expropriated investors' overall investment. ${ }^{38}$ In practice, investment tribunals also possess an inherent "inborn malfunction" of insufficient anti-corruption investigative powers. ${ }^{39}$

\section{E. Tribunal's Congenital Inadequate Power in Corruption Investigations}

Undoubtedly, 2007 the outcomes of Siemens $A G$ revealed, to some extent, the "ruthless" reality that investment tribunals lack sufficient instruments and equipment to pursue an anti-corruption criminal investigation. ${ }^{40}$ Traditionally, arbitration was not perceived as an ideal venue for adjudicating claims of bribery and/or corruption. The lack of confidence in, or even resistance to, the arbitration of 
corruption claims in international investment arbitration proceedings was based on the view of the investment tribunals' limited jurisdiction, which addressed concerns about the tribunals' restricted power to compel the production of evidenceparticularly in comparison to that of domestic regulatory authorities whose natural functions are to investigate and prosecute crimes of corruption (for example, bribery). More importantly, the tribunals lack any authority to impose criminal penalties. $^{41}$

Although it is undeniable that investment tribunals face some real difficulties, this does not necessarily mean that the investment tribunals should not be able to engage in repudiating the corrupt misconduct in international investment activities. After all, tribunals have enough leeway and leverage to find a fair and just result to enable settlement of the investment disputes eventually. ${ }^{42}$

As anti-corruption functions between the ICSID and domestic enforcement authorities do overlap, the successful anti-corruption coordinative legal framework between these two kinds of anti-corruption organs should guarantee the effectiveness of an international corruption-combating campaign. Such a mechanism enables to protect the global public interest in international investment law, realizing the ultimate goal of constructing a "clean and beautiful" ${ }^{43}$ international investment community.

\section{Legal Basis for Constructing AN Anti-Corruption CoOrdinative Mechanism}

\section{A. Treaties on Combating Corruption in International Business Transactions}

The Convention on Combating Bribery ${ }^{45}$ of Foreign Public Officials in International Business Transactions, ratified by the Organization for Economic Co-operation and Development in 1997 (hereinafter OECD Convention) regulates the issue of "bribery." ${ }^{46}$ Two years later, another regional document came into being-the Criminal Law Convention on Corruption of the Council of Europe in 1999 (hereinafter Council of Europe Convention). Compared to the OECD Convention, the Council of Europe Convention is much broader in regulatory scope: member states must penalize even "soft corruption," money laundering, accounting misconduct, and any participatory acts (Articles 12-15). Moreover, the latter criminalizes the bribery 
to domestic public officials, judges, members of parliament in international institutions, as well as in the private sector (Articles 2-11). ${ }^{47}$ In addition, the United Nations Convention against Corruption in "Chapter III Criminalization and Law Enforcement" enumerates 11 types of corrupt (criminal) misconducts: bribery of national public officials; bribery of foreign public officials and officials of public international organizations; embezzlement, misappropriation or other diversions of property by a public official; trading in influence; abuse of functions; illicit enrichment; bribery in the private sector; embezzlement of property in the private sector; laundering of proceeds of crime; concealment; obstruction of justice. ${ }^{48}$

Notably, the United States-Mexico-Canada Agreement 2018 emphasizes the relevance of collective countermeasures against corruption by the contracting states and the importance of anti-corruption cooperation and coordination with other international organizations. ${ }^{49}$ In Chapter 27, especially, "Anticorruption" are defined by a total of 9 Articles, namely "Definitions"; "Scope"; "Measures to Combat Corruption"; "Promoting Integrity among Public Officials"; "Participation of Private Sector and Society"; "Application and Enforcement of Anticorruption Laws"; "Relation to Other Agreements"; "Dispute Settlement"; and "Cooperation.",

\section{B. Domestic Legislation for Combating Corruption in International Economic Activities.}

In the US, the Foreign Corrupt Practices Act (FCPA) was passed by Congress in December 1977. ${ }^{51}$ The past decade has seen a significant increase in the enforcement of anti-corruption statutes such as the FCPA. ${ }^{52}$ The FCPA takes a supply-side approach to punish and prevent corruption, reducing the supply of bribes to foreign officials by punishing bribe-paying corporations-rather than attempting to reduce the demand for bribes by punishing bribe-taking officials. ${ }^{53}$ However, the 1998 revision of the FCPA applies not only to domestic business sectors, but also to foreign and domestic issuers of securities listed on the US stock exchanges who commit violations outside the US, as well as foreign companies that commit acts in furtherance of a violation "while in the territory of the United States.",

Compared to the FCPA, the UK Bribery Act 2010 is substantially broader in scope and stricter in enforcement. Whereas the FCPA criminalizes only the payment of bribes to foreign officials, the UK Bribery Act 2010 criminalizes the 
payment of bribes to foreign public officials, as well as to private individuals. Unlike the FCPA, the UK Bribery Act also criminalizes the receipt of bribes. Though the FCPA provides an exception for facilitation payments intended "to expedite or to secure the performance of a routine governmental action," the UK Bribery Act provides no such exception. ${ }^{55}$

Fortunately, other countries have also shown an increased interest in legislating domestic laws concerning international judicial assistance in the criminal domain, of which the International Criminal Judicial Assistance Law of the People's Republic of China 2018 (ICJAL) is a typical example. Article 67 of the ICJAL stipulates: "The People's Republic of China and relevant international organizations that carry out criminal judicial assistance shall be governed mutatis mutandis to the provisions of this Law." This provision underlies the explicit legal foundation for the construction of anti-corruption criminal judicial cooperation mechanisms between the ICSID and Chinese domestic enforcement authorities. ICJAL "is enacted to ensure the normal conduct of international criminal judicial assistance, strengthen international cooperation in the field of criminal justice, effectively punish crime, protect the legitimate rights and interests of individuals and organizations, and safeguard national interests and social order., ${ }^{, 56}$

In fact, the current anti-corruption governance in the international financial/ business arena is expanding to the corruption regulatory scope and enhancing anti-corruption mechanisms. When confronted with the real situations where the host state becomes enthusiastic with the corruption defense as proceeding skills to frustrate foreign investors' claims, investment tribunals encounter two layers of pressure: the scope expansion of corruption defenses invoked mainly by host state and increasing number of cases of corruption-involved investment disputes. ${ }^{57}$ These factors highlight the necessity and significance of establishing the anti-corruption coordinative mechanisms between the ICSID and domestic enforcement authorities. 


\section{Anti-corruption Coordinative Strategies OF THE ICSID TRIBUNALS}

\section{A. ICSID Arbitration Proceedings Anterior to Domestic Anti-corruption Enforcement Procedures}

\section{Preconditions for Successful Invocations of Corruption Defenses}

Given that the current jurisprudence and practice of ICSID's anti-corruption arbitrations are inclined to treat the foreign investors' interests and the host states' right asymmetrically, the host states' successful invocation of the corruption defense needs to be preconditioned as follows. ${ }^{58}$

First, investment tribunals request that the host state presents evidence that has commenced with public prosecution against officials suspicious of jointly being involved in the corruption misconduct. ${ }^{59}$ Second, the host state shall prove that it has implemented anti-corruption criteria as required under its legal framework, or taken effective countermeasures to fight against corruption. ${ }^{60}$ Furthermore, tribunals should consider the host state's contributory responsibilities in any investors' corrupt activities, so that the host state can only invoke the corruption defense when the host state is innocent. ${ }^{61}$ It is strongly proposed that any commitment made by the host state to initiate a domestic anti-corruption investigation against corrupt officials shall be based on the defense successfully invoked. ${ }^{62}$ Generally in the settlement of investment disputes, the subsequent domestic anti-corruption investigations against the host state's high officials are urgently encouraged following the successful invocation of the corruption defense by the host state.

\section{Domestic Judicial Assistance in International Corruption Combating Cooperation} As the foreign investors commit corruption generally within the host state's territory, the ICSID tribunals" "inborn functional insufficiency" restricts ascertaining evidence of the investors' corruption. In practice, arbitral tribunals have already revealed their inefficiencies in handling the host state's corruption defense against foreign investors. ${ }^{64}$ As far as tribunals are concerned, they should require that the host states follow the "clear and convincing evidence" standard and bear the evidentiary burden as well. However, tribunals are encouraged to seek judicial assistance from domestic anti-corruption enforcement authorities. ${ }^{66}$ 
Based on Article 13 of the ICJAL, since there is no criminal judicial assistance treaty between the ICSID and the Chinese government, the ICSID should make a reciprocal commitment to the latter if ICSID tribunals intend to seek judicial assistance from China. The ICSID "submits criminal judicial assistance requests to the People's Republic of China" in a written form "in accordance with the provisions of the criminal judicial assistance treaty." included in the written request: "(1) the name of the requesting authority; (2) The nature of the case, the basic information of the persons involved and the facts of the crime; (3) The legal provisions applicable to this case; (4) The matter and purpose of the request; (5) the relationship between the requested matter and the case; (6) the time limit for which the request is expected to be executed; and (7) Other necessary information or additional requirements. ${ }^{, 68}$

In China, "Criminal judicial assistance between the People's Republic of China and foreign countries should be coordinated through the foreign relations agencies." ${ }^{69}$ Also, "the foreign relations agencies including the Ministry of Justice of the People's Republic of China are responsible for proposing, receiving and transmitting criminal judicial assistance requests, and dealing with other matters related to international criminal judicial assistance., ${ }^{, 70}$ As there is no criminal justice assistance treaty between China and the ICSID, "contact shall be made through diplomatic channels." 71 In light of Article 5 of the ICJAL, the ICSID can only submit an anti-corruption judicial assistance request to the Chinese government by way of the PRC Ministry of Foreign Affairs. Article 6 of the ICJAL provides:

China's State Supervision Commission, the Supreme People's Court, the Supreme People's Procuratorate, the Ministry of Public Security, the Ministry of National Security and other departments are the competent authorities for conducting international criminal judicial assistance. These authorities are then responsible to review the criminal judicial assistance requests submitted by foreign countries or international organizations according to the division of responsibilities, review and handle such requests forwarded by the foreign relations agencies, and undertake work related to international criminal judicial assistance. $^{72}$

As an independent international organization, the ICSID's request may be forwarded by China's foreign relations agencies first, and reviewed and handled by competent 
domestic authorities accordingly in the subsequent proceedings. ${ }^{73}$

\section{Domestic Authorities' Arranging Witnesses or Experts to Testify or} Assist in Anti-corruption Investigation

In the process of settling corruption-involved international investment disputes, the ICSID may request (if necessary) a foreign country (mainly the host state) to assist in arranging witnesses or experts either to testify within the territories of the country concerned by video/audio, or to assist in investigations. ${ }^{74}$ As stipulated in Article 36 of the ICJAL, the ICSID may "request the People's Republic of China to assist in arranging witnesses or experts to testify in foreign countries or to testify by video or audio, or to assist in investigations. ${ }^{, 75}$ Where the ICSID requests that China arrange for witnesses or experts to testify or assist in the investigation, the written request and accompanying materials shall state the following details accordingly: " (1) The name, gender, address, identity information, contact information and other materials that help to identify the witnesses and experts; (2) The purpose, necessity, time and place of the testimony or assistance in the investigation; (3) The rights and obligations of witnesses and experts; (4) Protection measures for witnesses and experts; (5) Subsidies to witnesses and experts; and (6) Other materials that contribute to the execution of the request." ${ }^{, 77}$ Upon request, the ICSID shall make a written undertaking regarding the treatment of the crimes committed by the witnesses or experts before they enter the foreign country to testify or assist in the investigation, and the status of their personal freedom together with the issue of any time limits for staying in the country. ${ }^{78}$

\section{The Amount Foreign Investors Lost and Subsequent Domestic Anti-corruption Penalties}

When the ICSID tribunal has made an unfavorable award against corrupt foreign investors before domestic anti-corruption authorities initiate commercial corruption investigations, can the final monetary penalties imposed by the domestic anti-corruption authorities be offset by the economic losses that the foreign investors suffered in the anterior ICSID arbitration? Bhojwani proposes affirmatively that "domestic anti-corruption penalties be offset by the amount an investor loses in arbitration." 79 This proposal entails reducing the violator's corruption penalty by the amount of its failed ICSID claim if the host state invokes 
the corruption defense. Foreign investors regard it attractive because it seeks to temper the price paid by corrupt investors, so that the combined effect of domestic anti-corruption enforcement and the corruption defense successfully invoked in investment arbitration may not act as a deterrent to direct foreign investment. ${ }^{80}$

However, the argument against offsetting the costs is based on an assumption that the offsetting "could potentially undermine the FCPA's supply-side approach to corruption. Both parties to mutual corruption are culpable, and capitulating to investors could do more harm than good by weakening the appearance of certainty attached to FCPA sanctions." ${ }^{81}$ Such concerns could be relieved for at least two reasons: (1) ICSID tribunals are strongly recommended to adopt a balanced approach to provide a more flexible solution to coordinate rights and duties between foreign investors and the host state, with which both parties can enjoy unequal social powers. To consider the host state's officials' contributory liabilities in joint corrupt misconduct when deciding foreign investors' penalties could never result in "capitulating to investors"; ${ }^{82}$ and (2) following the Principle of "No One Is to Be Punished Twice for One Offense," the economic losses awarded in anterior ICSID arbitration on the part of foreign investors are reasonably able to offset the final monetary penalties imposed by domestic anticorruption authorities. The relationship between the ICSID pecuniary obligations and domestic anti-corruption fines is analogous to that of the domestic court's financial penalties and domestic administrative fines. ${ }^{83}$ In this regard, Article 28 of the Law of the People's Republic of China on Administrative Penalty (2017 Amendment: hereinafter PRC Administrative Penalty Law) provides: "If an illegal act constitutes a crime, for which a People's Court imposes a fine on the party, and if an administrative organ has already done so, the amount of the fine imposed by the latter shall be made the same as that by the former." ${ }^{84}$

\section{Waiver of Unlawful Rights or Disgorgement of Unjust Compensation}

The ICSID tribunal in Siemens $A G$ found that Argentina's actions throughout the crisis constituted a "creeping" expropriation and ordered Argentina to compensate Siemens for USD 217 million. ${ }^{85}$ Shortly after the tribunal issued its award, however, "German prosecutors discovered Siemens had engaged in rather astonishing acts of systematic bribery around the world. ${ }^{, 86}$ Following its FCPA settlement in 2008, Siemens waived its right to the USD 217 million award that 
had been won against Argentina. Though it is unclear precisely why Siemens did so, its forfeiture of the award appears to be a normatively desirable result. If the ICSID tribunal had been aware of the Siemens' corruption facts, it almost certainly would have approved a corruption defense in favor of Argentina. ${ }^{87}$ Alternatively, had the investigation by German prosecutors never occurred, Siemens would have succeeded in reaping the benefits of its corrupt conduct by exploiting the disputeresolution provisions of a treaty whose protections it was not entitled to enjoy. ${ }^{88}$ Accordingly, to ensure the correct outcomes in the future, domestic anti-corruption authorities should require investors to waive their rights to ICSID awards (or to disgorge awards already paid) as a condition of prosecution agreements. In conformity with the maxim of "restitutio in integrum," the claimant's waiver of an award restores the parties to the positions they would have enjoyed had the respondent host state succeeded in asserting the corruption defense. ${ }^{89}$

When a respondent host state has paid the specific compensation rendered in an award, the "disgorged" payment might be used as follows: (1) to be forfeited to the investigating country's government; (2) to implement changes to the reporting and bookkeeping practices within the claimant corporation; (3) or to be placed into an anti-corruption fund to support anti-corruption efforts in the host state. ${ }^{90}$ Alternatively, the investor could return the funds to the host state, but doing so would achieve the same result as if the tribunal had recognized the host state's corruption defense. ${ }^{91}$ However, this would essentially permit the host state, as the sole subject, to reap the benefits of its corrupt conduct in a case that the officials are involved in corruption (for instance, taking bribes, etc.). The best solution might be thus to incorporate these elements, based on the subsequent domestic prosecuting authorities' best judgment in the given circumstances, in order to achieve the most righteous result. ${ }^{92}$

\section{B. Simultaneous Proceedings between the ICSID Arbitration and Domestic Anti-corruption Enforcement}

\section{Suspension of the Arbitration to Await the Result of Domestic Anti-corruption Investigations}

Fraport is a typical case in which the ICSID arbitration and domestic anticorruption investigations proceed simultaneously. ${ }^{93}$ In this case, the documents obtained from the Philippines' domestic corruption investigation could have been 
extremely useful to the ICSID tribunal in deciding the outcome of the investment dispute. ${ }^{94}$ However, the materials had not been handed over to the tribunal. Though the Philippines (respondent) factually submitted its application to suspend the arbitral proceedings to the tribunal pending the outcome of the domestic anti-corruption investigation, ${ }^{95}$ the tribunal unfortunately did not grant a stay. ${ }^{96}$ The tribunal's refusal in Fraport is difficult to comprehend, but it is estimated that future investment tribunals should continue to be reluctant to grant stays requested by the host states. ${ }^{97}$ The tribunal of Fraport finally decided in favor of the Philippines as the host state. ${ }^{98}$ In this case, the tribunal's arbitral jurisprudence is that the Fraport Company's investment was not made in accordance with the Philippines' laws and regulations. ${ }^{99}$ The information uncovered in the domestic anti-corruption investigation could have given the Philippines (respondent), a second avenue to victory. No doubt, the practical significance of the ICSID tribunals' not staying an arbitration proceedings and waiting for the outcome of domestic corruption investigations underscore the positive value of domestic anticorruption enforcement authorities' enhanced powers when collecting evidence. ${ }^{100}$ Although ICSID tribunals do have the legal power to compel the production of documents, such power is considerably weaker than the investigatory power vested in domestic anti-corruption enforcement authorities such as the US Department of Justice, Securities Exchange Commission, and the Federal Bureau of Investigation under the FCPA framework. ${ }^{101}$ Hence, to take advantage of the investigative resources of domestic anti-corruption enforcement authorities, the ICSID tribunals should make it their policy to ask for advice from domestic enforcement authorities about whether to stay proceedings pending the domestic anti-corruption investigation outcome. Of course, domestic enforcement authorities need to be prepared to make such recommendations. ${ }^{102}$

Currently, due to the case hearing durations, costs, and efficiency of dispute settling, some ICSID tribunals are not prepared to decide a stay of the arbitral proceedings. ${ }^{103}$ To avoid the failure of Siemens $A G$, the tribunals approved the stay applications raised by disputing parties. Investment tribunals should be more enthusiastic to collecting reliable information as much as possible to ensure their correct awards. Notably, a defective or even wrongful decision can be considered as the least efficient outcome of the investment dispute settlement. ${ }^{104}$ 


\section{The Foreign Investor Claimants for the Stay of Arbitral Proceedings}

Undoubtedly, domestic anti-corruption enforcement authorities are capable of finding any evidence which might have escaped the tribunals' notice. When corruption-involved investment disputes are settled simultaneously by investment tribunals and domestic enforcement bodies, the latter should encourage investor claimants to submit arbitration stay claims to the tribunals for the sake of any investigative advantages possessed by domestic enforcement authorities. ${ }^{105}$

A relaxed exterior atmosphere may be created for domestic anti-corruption enforcement authorities to conduct a full investigation, while the outcome of a corruption investigation by domestic enforcement bodies may also help provide an arbitral basis for a tribunal's dispute settlements. Arbitration is purported to be greatly facilitated after the outcome of a domestic anti-corruption investigation. ${ }^{106}$ Investment tribunals are conceivably willing to enlist as many domestic anticorruption authorities as possible in the role of competent "detectives," to ensure that the awards rendered are based on objective and comprehensive facts. ${ }^{107}$ Domestic anti-corruption enforcement authorities need to be ready to offer assistance. In this case, after all, the already determined ICSID awards based on accurate information will not only reward the honest and faithful foreign investors, but also hold those investors who have committed corrupt activities accountable for their crimes and unable to escape from legal punishment. ${ }^{108}$

In conclusion, tribunals should be more willing to grant stays requested by foreign investor claimants because the latter could decide to drop their claims anyway, in the end. As any domestic anti-corruption investigation deepens, foreign investors' corruption evidence will gradually be disclosed and controlled by the domestic anti-corruption authorities, so that the withdrawal of any arbitration applications on the side of foreign investors may be a "wise decision.",109

\section{Domestic Anti-corruption Enforcement Authorities and the Outcome of Corruption Investigation with the ICSID Tribunals}

Domestic anti-corruption enforcement bodies can adopt different strategies when interacting with ICSID tribunals, depending on the result of any domestic corruption investigations. Unless corruption evidence has been uncovered on the part of foreign investors by domestic investigative authorities, the authorities can notify the tribunals of the foreign investors' innocence. ${ }^{110}$ However, as the 
corruption defense raised by a respondent host state becomes groundless in these circumstances, the host state will predictably be reluctant to disclose the innocent investigative outcome to the ICSID tribunals. ${ }^{111}$ Therefore, when the full coordination from domestic anti-corruption enforcement authorities should be conditioned, the judicial assistance treaty has been entered into between such international organizations as the ICSID with any host state government. In this case, internal government agencies undertake legal obligations according to municipal laws; mutual judicial assistance between the ICSID and any domestic enforcement authorities otherwise is provided based on reciprocal principle. ${ }^{112}$

However, if domestic enforcement bodies discover solid evidence of corruption, the respondent host state is expected to disclose the information to the investment tribunal under the current investment arbitral jurisprudence. It may predictably yield the inclination of jurisdiction over the dispute by investment tribunals, thereby resulting in the foreign investors' claims becoming unsupported. ${ }^{113}$ Meanwhile, internal enforcement authorities in the host state can also seek to force foreign investors to withdraw the ICSID arbitration claims. ${ }^{114}$ Hence, investors can feel deprived of protective rights under relevant BITs. In acknowledgment of the actions of the Siemens Company, foreign investors should certainly consider accepting the terms offered by a host state or could become subject to imprisonment penalties and financial fines, as well as global damage to their reputation. $^{115}$

\section{Domestic Anti-corruption Enforcement Procedures Anterior to ICSID Arbitration Proceedings}

\section{Domestic Anti-corruption Enforcement Procedures: A Case of China}

\section{(1) China's Anti-corruption Enforcement Authorities.}

In China, the anti-corruption enforcement mission is jointly performed by various national or local state authorities such as People's Procuratorate, Public Security Organs, People's Courts, the Commerce Department, the Development and Reform Commission, Administration for Market Regulation, ${ }^{116}$ Securities Regulatory Organs and Supervisory Commissions at central or local levels. ${ }^{117}$ The People's Procuratorate and Public Security Organs have anti-corruption investigative powers and are responsible for prosecuting criminal charges against foreign investors. In addition, People's Courts are judicial organs that consider merits 
in criminal, administrative, and civil lawsuits. The other enforcement authorities primarily exercise administrative functions to regulate foreign investors' corrupt misconducts. Notably, China's Supervisory Organs are now playing a larger, more significant role in combating corruption since the Supervision Law of the People's Republic of China was adopted at the 1st Session of the Standing Committee of the Thirteenth National People's Congress, on March 20, 2018. ${ }^{118}$

\section{(2) Penalty Outcomes of China's Domestic Anti-corruption Enforcement.}

Penalties for violations of China's anti-corruption legislation include criminal penalties as well as administrative punishments. Foreign investors' corrupt misconducts judged to be criminal offenses are subject to the principle of "territorial criminal jurisdiction" stipulated in Article 6 of the Criminal Law of the People's Republic of China (2017 Amendment). ${ }^{119}$ According to Article 32 of the Criminal Law, criminal punishments are divided into principal and supplementary punishments. The principal punishment types are: (a) control; (b) criminal detention; (c) fixed-term imprisonment; (d) life imprisonment; and (e) the death penalty (Article 33). ${ }^{120}$ The supplementary punishment types are: (a) fines; (b) deprivation of political rights and (c) confiscation of property. ${ }^{121}$ Supplementary punishments can also be applied independently according to Article 34 of the PRC Criminal Law. When foreign investors are found guilty of criminal offenses, deportation may be included as an independent or supplementary type punishment, as per Article 35 of the PRC Criminal Law.

Concerning foreign investors' administrative offenses within China's territory, penalties need to be imposed for investors' violations of the domestic administrative order. The administrative penalties shall be prescribed by laws, rules, and/or regulations according to the PRC Administrative Penalty Law 2017 and implemented by administrative organs in compliance with procedures prescribed by the Law. ${ }^{122}$ Administrative penalties are categorized into: (a) disciplinary warnings; (b) fines; (c) confiscation of illegal gains or confiscation of unlawful property or things of value; (d) ordering for suspension of production or business; (e) temporary suspension or rescission of any permits or temporary suspension or rescission of license; (f) administrative detention; and (g) others as prescribed by laws and administrative rules and regulations. ${ }^{123}$ Per Article 7 of the PRC Administrative Penalty Law 2017, foreign investors and their investment 
organizations are subject to administrative penalty because their violations of law shall bear civil liability for damage done to others by their illegal acts in China.

In the case of the Anti-Unfair Competition Law of the People's Republic of China (Amended in 2019), foreign investors should not seek transaction opportunities or competitive edges by bribing the following entities or individuals with property or by any other means such as: (a) an employee of the other party to a transaction; (b) the entity or individual authorized by the other party to a transaction to handle relevant affairs; and (c) an entity or an individual that uses power or influence to affect a transaction. ${ }^{124}$ Although the PRC Anti-Unfair Competition Law does not stipulate the minimum criterion for initiating an administrative investigation into commercial corruption, when a business (including foreign investors) bribes another person in violation of Article 7 of this Law, the supervisory inspection department shall confiscate its illegally-gained income, and impose a fine of not less than RMB 100,000 but no more than RMB three million. If the bribery is considered significant or major, the business license shall be revoked. ${ }^{125}$

\section{(3) Specific Anti-corruption Enforcement Law for Foreign Investors in China}

There are no specific anti-corruption enforcement laws for foreign investors or investments in China equivalent to the FCPA. The legal regulations and punishments for foreign investors' corrupt activities in China are scattered through various forms of domestic criminal, administrative and economic laws in China. Even in the Foreign Investment Law of the People's Republic of China (FIL), ${ }^{126}$ there are no specific provisions directed at fighting corrupt misbehaviors committed by foreign investors or investments except for the general stipulation of an "in accordance with the laws of the host state" clause. The FIL provides: "Foreign investors and foreign-funded enterprises conducting investing activities within China shall abide by the laws and regulations of China, and neither compromise China's national security nor cause damage to the public interest." ${ }^{\text {"27 }}$ Regarding the legal liabilities of foreign investors for any corrupt misconducts, Article 38 of the FIL only offers an obscure solution, which states that: "the violations of laws and regulations committed by foreign investors and foreign-funded enterprises shall be investigated by the relevant departments according to the law and included in the credit information system according to the relevant provisions issued by the state." 128 


\section{ICSID Arbitral Proceedings after Anti-corruption Enforcement Penalties}

The investigative results of the domestic anti-corruption enforcement agencies against foreign investors may in no way affect investors' ICSID arbitration claim rights. If the investigative outcome is "innocent," it is unquestionable that the investors will apply for investment arbitration based on the host state's consent of ICSID jurisdiction over the government regulatory and supervisory measures. Even when an investigative result yields a positive answer, the investors cannot be prevented from exercising the rights of the initiating investment arbitration regarding the damage caused by the host state. ${ }^{129}$ Three different case scenarios are described below. ${ }^{130}$

Firstly, foreign investors' arbitration claim rights that the host state's infringement facts may not be generally deprived after they have received the corresponding anti-corruption penalties based on the "non-repeated penalty" law principle. $^{131}$

Secondly, since the foreign investors' corrupt misconducts are void $a b$ initio, the doctrine of restitutio in integrum restores the legal status of certain parties to the exact states when they were just standing before the corruption occurred. ${ }^{132}$ Consequently, the bribes taken by high officials in the host state shall be confiscated whereas the bribes offered by foreign investors may be nonreturnable. In practice, investors' corrupt activities fall into one of two categories: (1) the foreign investor and investments are the object of corruption itself, or (2) the foreign investor and investments get involved with corrupt practices during daily operations. The first situation would occur at the establishment stage of foreign investment. Initiation of the foreign investment conflicts with the domestic law of the host state, and the "unqualified" investment shall not be consequently legal and thus protected. ${ }^{133}$ The second situation would occur where foreign investors commit corrupt misconducts during day-to-day transactions of the investment entities after the business has been lawfully created. Once the investors have received the corresponding penalties, their legal statuses should "restore" to the originally normal states as if they had never embarked on the corrupt misconduct and activities. ${ }^{134}$ In the first situation, it can be further divided into 2 sub-situations: (1) foreign investors may enjoy the arbitration claim rights as "qualified investors" in situations where the foreign investments successfully acquire legal access to the host state market at a later time; and (2) the investments 
concerned remain unlawfully eligible for access to the host state market all the time, that is, the foreign investor has not taken any actions to rectify the initially defective investment into a lawfully "qualified" investment once access to the host state market has been established. ${ }^{135}$ However, the specific "unlawfully qualified" foreign investment should still be protected under either international law ${ }^{136}$ or domestic law ${ }^{137}$ frameworks. Additionally, based on the "Estoppel" Principle, the host state should recognize contributory liabilities in previously offering permission for market access to the foreign investor, especially if the examining official has taken bribes. ${ }^{138}$ In the second situation, foreign investors' status as "qualified investors" remains the same after having paid the corresponding domestic penalties imposed by anti-corruption enforcement authorities in the host country. ${ }^{139}$

Thirdly, according to the anti-corruption rules in some countries such as China, even though the foreign investors' corrupt misconducts are subject to criminal penalties, which are usually executed in the forms of "fixed-term imprisonment" or "additional fines," they generally are not necessarily subject to "the forfeiture of property". ${ }^{140}$ The host state may never, in an imposing manner, be able to implement expropriation or similar measures equivalent to expropriation which amount to confiscating foreign investors' assets as a result of investors' having committed corrupt misbehaviors. Therefore, investment arbitration claim rights naturally conferred to investors should appear to be protected. ${ }^{141}$

\section{Conclusion}

As the international treaties governing corruption has been developing on the global level, domestic enforcement statutes like the FCPA have dramatically increased for combating corrupt international investments. As investment tribunals' incompetency in handling anti-corruption investigation and incidental cases that have subsequently proven to be incorrectly decided such as Siemens $A G$, international investment arbitration institutions including the ICSID are now playing a somewhat "passive" role when confronted with corruption involved investment disputes. The current arbitral jurisprudence is subject to fierce criticism. It would makes compromised and inequitable settlements between foreign investors and the host state. The 
theoretically suggested anti-corruption coordinative mechanism between the ICSID and domestic enforcement authorities would undoubtedly exert a valuable, practical, and positive influence upon the present dilemma faced by investment tribunals in solving corruption-involved investment disputes. The ICJAL is a solid domestic legal basis for establishing such a coordinative international criminal judicial assistance mechanism between international organizations (e.g., ICSID) and the domestic anti-corruption enforcement authorities. Implementation of the ICJAL enhances China's remarkable image as a responsible and enlightened sovereign State, repudiating corruption in an internationally coordinated manner.

\section{REFERENCES}

1. M. Halpern, Corruption as a Complete Defense in Investment Arbitration or Part of a Balance, 23 Willamette J. Int'L L. \& Dis. Res. 297-317 (2016).

2. OECD, Convention on Combating Bribery of Foreign Public Officials in International Business Transactions, Dec. 18, 1997, 37 I.L.M. 1 (1998).

3. A. Kulick, Global Public Interest in International Investment Law 309 (2012).

4. H. Raeschke-Kessler \& D. Gottwald, Corruption in Foreign Investment-Contracts and Dispute Settlement Between Investors, States, and Agents, 9 J. World Inv. \& Trade 7 (2008).

5. E.g., Fraport AG Frankfurt Airport Services Worldwide v. Republic of the Phil., ICSID Case No. ARB/03/25, Award, 401-6 (Aug. 16, 2007), available at http://italaw.com/ documents/FraportAward.pdf; Inceysa Vallisoletana, S.L. v. Republic of El Sal., ICSID Case No. ARB/03/26, Award, 250-52 (Aug. 2, 2006), available at http://italaw.com/ documents/Inceysa_Vallisoletana_en_001.pdf; Plama Consortium Ltd. v. Republic of Bulg., ICSID Case No. ARB/03/24, Award, 321 (Aug. 27, 2008), available at http:// italaw.com/documents/PlamaBulgariaAward.pdf; World Duty Free Co. v. Republic of Kenya, ICSID Case No. ARB/00/7, Award 157 (Oct. 4, 2006), 46 I.L.M. 339 (2007).

6. Wena Hotels Ltd. v. Arab Republic of Egypt, ICSID Case No. ARB/98/4, Award 111-12 \& 132 (Dec. 8, 2000), 41 I.L.M. 896 (2002).

7. M. Losco., Note: Streamlining the Corruption Defense: A Proposed Framework for FCPA-ICSID Interaction, 63 DuKE L. J. 1222 (2014).

8. Id. at 1228 .

9. Fraport AG Frankfurt Airport Services Worldwide v. Republic of the Phil., ICSID Case 
No. ARB/03/25, Award 281 (Aug. 16, 2007).

10. Supra note 7, at 1225 .

11. Inceysa Vallisoletana, ICSID Case No. ARB/03/26, Award 83 (Aug. 2, 2006).

12. Plama Consortium Ltd. v. Republic of Bulg., ICSID Case No. ARB/03/24, Award 97-8 (Aug. 27, 2008), available at http://italaw.com/documents/PlamaBulgariaAward.pdf.

13. Hongwu Yin, The Construction of Anti-corruption Coordinative Mechanism between ICSID and Domestic Enforcement Authorities: Causes, Legal Foundation and Strategies [ICSID与内国执法机关间反腐协作机制的构建: 缘起、法律基础与策略], 2 WUHAN U. INT'L L. REv. [武大国际法评论] 104 (2020).

14. Id.

15. Biwater Gauff (Tanzania) Ltd v. Tanzania (ICSID Case No. ARB/05/22, Award ๆ 310 (July 24, 2008).

16. China-Germany BIT (1983), art. 1.

17. China-Germany BIT (2003), art. 1.

18. Hongwu Yin, The Evolution of Chinese Bilateral Treaties-The Multilateralization OF INTERNATIONAL INVESTMENT LAW AS The SETting [中国双边投资条约的演进-以国际投资法 趋同化为背景] 105 (2017).

19. Supra note 7, at 1224-26.

20. Supra note 9 , at 346.

21. Some scholars show concerns that if future tribunals continue to adhere to the same arbitral jurisprudence, the "estoppels" cause will rarely be asserted. See J. Yackee, Investment Treaties and Investor Corruption: An Emergent Defense for Host States?, 52 VA. J. INT'L L. 741-2 (2012).

22. Supra note 9 , at 396.

23. Hongwu Yin, On the Difficulties of ICSID Tribunals' Dealing with Host State's Corruption Defense and the Solutions-Taking Tribunals' Denial of Jurisdiction as the Cut-Point [ICSID仲裁庭应对东道国腐败抗辩的困境及其解决-以仲裁庭对涉腐投资主张无管 辖权为切入点]. 4 J. SOCIAL SCI. HunAN NORMAL U. [湖南师范大学社会科学学报] 76 (2019).

24. Supra note 7, at 1228-9.

25. E.g., Siag v. Arab Republic of Egypt tribunal has applied a "clear and convincing evidence" standard. See Waguih Elie George Siag and Clorinda Vecchi v. Arab Republic of Egypt, ICSID Case No. ARB/05/15, Award 326 (June 1, 2009), available at http:// italaw.com/sites/default/files/casedocuments/ita0786_0.pdf.

26. Supra note 9 , at 47.

27. Supra note 25 , at 325 .

28. Id. at 324-6.

29. Wena Hotels Ltd. v. Arab Republic of Egypt, ICSID Case No. ARB/98/4, Award (Dec. 8, 2000). See F. Haugeneder \& C. Liebscher, Corruption and Investment Arbitration: Substantive Standards and Proof, in Austrian Arb. Y.B. 549-50 (C. Klausegger et al. 
eds., 2009).

30. TSA Spectrum de Argentina S.A. v. Argentine Republic, ICSID Case No. ARB/05/5, Award 172 (Dec. 19, 2008). See also D. Thomson, How to Deal with Corruption Allegations, Global Arb. Rev. (Nov. 15, 2013), available at http:/globalarbitrationreview.com/news/ article/32055/how-deal-corruptionallegations.

31. Thomson, $i d$.

32. Supra note 25, at 4 (Award: Dissenting Opinion of Professor Francisco Orrego Vicuna).

33. Based on the existing international investment arbitral jurisprudence, when a foreign investor violates the treaty-based "in accordance" provision, there arouses the host state's corruption defense, the remedy has become jurisdictional in nature.

34. ICSID Case No. ARB/00/7, supra note 5, at 6 (Award).

35. Id. at $164 \& 186$ (Award).

36. Supra note 13 , at 106.

37. Bribery Act $\S 7(2)$. See generally P. Alldridge, The U.K. Bribery Act: "The Caffeinated Younger Sibling of the FCPA,” 73 Оніо State L. J. 1181-210 (2012).

38. Supra note 23, at 73-82.

39. A. Kulick \& C. Wendler, A Corrupt Way To Handle Corruption?: Thoughts on the Recent ICSID Case Law on Corruption, 37 Legal Issues Econ. Integration 83 (2010).

40. Siemens AG v. Argentine Republic, ICSID Case No. ARB/02/8, Award 308-9 (Feb. 6, 2007).

41. Supra note 39 , at $61 \& 83$.

42. Id. at 83 .

43. China's Concept of "A Common Community for Mankind with a Shared Future" is characterized by "a new type of international relations" and aims to "build an open, inclusive, clean and beautiful world that enjoys lasting peace, universal security, and common prosperity." Chinese President Xi Jinping reiterated such a vision in his public speeches both at home and abroad. See Xuequan Mu, Xi calls for building SCO community with a shared future, XINHUANET, June 10, 2018, available at http://www. xinhuanet.com/english/2018-06/10/c_137243964_2.htm. In the author's viewpoint, the construction of a "clean and beautiful" international investment community is the indispensable part of building "A Common Community for Mankind with a Shared Future."

44. Supra note 13, at 107.

45. Factually, "bribery" defined in Article 1 (1) of the Convention refers mainly to "bribeoffering," not covering "bribe-taking."

46. The practice proves that the OECD Convention's influence is quite limited in the context of international investment arbitration. Supra note 3, at 311.

47. Like the OECD Convention, Article 19 of the Criminal Law Convention on Corruption of the Council of Europe only obliges States to take measures under their domestic law to 
penalize various forms of corruption. It does not thus establish direct obligations vis-à-vis corruption in the international relationship of the host state and the investor.

48. The United Nations Convention against Corruption, arts. 15-25, available at http://www. lawinfochina.com/display.aspx?id=364\&lib=tax.

49. US-Mexico-Canada Agreement 2018, art. 27.9 (Cooperation 4), available at https://ustr. gov/trade-agreements/free-trade-agreements/united-states-mexico-canada-agreement.

50. Id.

51. T. Krever, Curbing Corruption? The Efficacy of the Foreign Corrupt Practices Act, 33 N.C. J. Int'L L. \& Com. Reg. 87 (2007). See also L. Ross, Note: Using Foreign Relations Law to Limit Extraterritorial Application of the Foreign Corrupt Practices Act, 62 DuKE L. J. 451-2 (2012).

52. From 2004 to 2009, the number of new enforcement actions increased from five to over forty. See Ross, id. at 460.

53. D. Weiss, Note: The Foreign Corrupt Practices Act, SEC Disgorgement of Profits, and the Evolving International Bribery Regime: Weighing Proportionality, Retribution, and Deterrence, 30 Мich. J. INT'L L. 471-7 (2009).

54. 15 U.S.C. $§ 78 d d-3(a)$.

55. S. Hunter, A Comparative Analysis of the Foreign Corrupt Practices Act and the U.K. Bribery Act, and the Practical Implications of Both on International Business, 18 ILSA J. INT'L \& Comp. L. 89-109 (2011).

56. ICJAL art. 1.

57. Supra note 13 , at 108.

58. Supra note 7, at 1232 .

59. B. Greenwald, The Viability of Corruption Defenses in Investment Arbitration When the State Does Not Prosecute, EJIL: Talks!, Apr. 15, 2015, available at https://www.ejiltalk. org/the-viability-of-corruption-defenses-in-investment-arbitration-when-the-state-doesnot-prosecute.

60. Tidarat Sinlapapiromsuk, The Legal Consequences of Investor Corruption in InvestorState Disputes: How Should the System Proceed?, 3 TDM (Corruption \& Arbitration) 33 (2013).

61. Supra note 23, at 73-82.

62. Supra note 13, at 109.

63. Id.

64. Inceysa Vallisoletana S.L. v. Republic of El Salvador, ICSID Case No. ARB/03/26, Award, ๆ 53 (Aug. 2, 2006); World Duty Free v. Kenya, ICSID Case No. ARB/00/7, ๆ 161 (Oct. 4, 2006); Fraport AG Frankfurt Airport Services Worldwide v. The Republic of the Philippines, ICSID Case No. ARB/03/25, ๆ 345 (Aug. 16, 2007).

65. Waguih Elie George Siag and Clorinda Vecchi v. Arab Republic of Egypt, supra note 25, at 326 . 
66. Supra note 13, at 109.

67. ICJAL art. 13.

68. Id.

69. Id. art. 5(1).

70. Id. art. 5(2).

71. Id. art. 5(3).

72. Id. art. 6(1).

73. Id. art. 6(2).

74. Supra note 13, at 110.

75. ICJAL art. 36(1).

76. Id. art. 36(2).

77. Id. art. 32.

78. Id. art. 36.

79. R. Bhojwani, Deterring Global Bribery: Where Public and Private Enforcement Collide, 66 Colum. L. Rev. 122 (2012).

80. Supra note 7, at 1235.

81. Id. at $1235-6$.

82. Id. at 1236 .

83. Supra note 13, at 111.

84. PRC Administrative Penalty Law 2017, art. 28.

85. Siemens AG v. Argentine Republic, supra note 40, at 262-5, 273 \& 308-9 (Award).

86. R. Zachary Torres-Fowler, Note: Undermining ICSID: How the Global Antibribery Regime Impairs Investor-State Arbitration, 52 VA. J. INT'L L. 1027 (2012).

87. Supra note 13 , at 110.

88. Supra note 7, at 1235.

89. World Duty Free Co. v. Republic of Kenya, supra note 5, at 164 \& 186 (Award).

90. Supra note 7, at 1234.

91. Id.

92. Supra note 13, at 108-9.

93. Fraport AG Frankfurt Airport Services Worldwide v. Republic of the Phil., supra note 5, at 47 (Award).

94. Supra note 13, at 108-9.

95. Fraport AG Frankfurt Airport Services Worldwide v. Republic of the Phil., supra note 5, at 47 (Award).

96. Id. at 17 (Procedural Order No. 21, Jan. 6, 2006).

97. Id. at 47 (Award).

98. Supra note 7, at 1239.

99. Id.

100. Supra note 13, at 110. 
101. Supra note 7, at 1240.

102. Id.

103. Fraport AG Frankfurt Airport Services Worldwide v. Republic of the Phil., supra note 5, at 47 (Award).

104. Supra note 23 , at 80 .

105. Supra note 7, at 1240.

106. Id.

107. Id.

108. Id.

109. Supra note 13 , at 108-9.

110. Supra note 7, at 1241.

111. Supra note 13, at 111.

112. Id. at 109.

113. ICJAL art. 4.

114. Supra note 7, at 1241.

115. Supra note 53, at 511-1.

116. PRC Anti-unfair Competition Law, art. 8.

117. PRC Supervision Law, art. 3.

118. Order of the President of the People's Republic of China: Xi Jinping (No. 3, 2018).

119. PRC Criminal Law 2017, art. 6(1). It provides: "This law is applicable to all who commit crimes within the territory of the PRC except as specially stipulated by law."

120. Id. art. 33.

121. Id. art. 34.

122. PRC Administrative Penalty Law, art. 3.

123. Id. art. 8.

124. PRC Anti-unfair Competition Law 2019, art. 7.

125. Id. art. 19.

126. Adopted at the 2nd Session of the Thirteenth National People's Congress of the People's Republic of China on March 15, 2019.

127. FIL art. 6.

128. Id. art. 38.

129. Hongwu Yin, Construction of a Coordinative Mechanism between ICSID and Domestic Anti-corruption Enforcement Authorities in Corruption-related International Investment Arbitrations [论涉腐国际投资仲裁中ICSID与内国反腐执法机关间协作机制的构建], $4 \mathrm{~J}$. INT'L ECON. L. [国际经济法学刊] 112-3 (2020).

130. Id.

131. Id.

132. Id.

133. Id. 
134. Id.

135. Id.

136. The foreign "investor" is able to file its application for arbitration as the "national of the other state" on the basis of relevant BIT.

137. PRC Anti-unfair Competition Law 2017, art. 19.

138. Fraport AG Frankfurt Airport Services Worldwide v. Republic of the Phil., supra note 5, at 346 (Award).

139. Supra note 129 , at 113.

140. PRC Criminal Law 2017, art. 390.

141. Supra note 129 , at $102 \& 113$. 
